\title{
An Unusually Big Cervical Fibroid Polyp: A Case Report
}

\section{Shireen Akhter Khanam ${ }^{1^{*}}$ \\ Fahmida Rashid ${ }^{1}$ \\ Shahanara Chowdhury ${ }^{1}$}

'Department of Obstetrics \& Gynaecology Chittagong Medical College Chittagong, Bangladesh.
*Correspondence to:

\section{Dr. Shireen Akhter Khanam} Assistant Professor

Department of Obstetrics \& Gynaecology Chittagong Medical College

Chittagong, Bangladesh.

Mobile : +8801817 708042

E-mail-shireendr23@yahoo.com

\begin{abstract}
Fibroid Uterus is the most common benign solid tumor in female. Most of fibroids situated in the body of the uterus, cervical myoma account $3 \%-8 \%$ of uterine myoma. Cervical myoma are uncommon in different presentation, resembling inversion of uterus, malignancy \& various sizes are reported in literature. A case of big cervical fibroid polyp has been reported here. Patient presented something coming down per vagina with foul smelling discharge. On examinations there was a hugely enlarged, infected mass about $15 \mathrm{~cm} \times 12 \mathrm{~cm}$ which was arising from posterior lip of the cervix \& outside the introitus. As the patient was 45 years $\&$ had menorrhagia, Non Descend Vaginal Hysterectomy (NDVH) was done without resecting the polyp priorly. Patient was discharged in good condition. Histopathology confirmed the diagnosis and reported leiomyoma with areas of degeneration which was mainly composed of involuntary smooth muscle cells \& fibrous connective tissue from cervix which probably expelled out as a polyp attached to posterior lip of cervix.
\end{abstract}

Key words: Cervical fibroid; Polyp; Non descend vaginal hysterectomy.

\section{INTRODUCTION}

Cervical fibroid is uncommon \& only $1 \%-2 \%$ are confined to cervix. Cervical fibroid polyp usually arises from the ectocervix $\&$ from its posterior lip ${ }^{1}$. It may be small \& usually single. At times, it is big enough to distend the vagina or even comes out of the introitus, confusing the diagnosis of uterine inversion ${ }^{1}$. This tumor can frequently present with heaviness in the vagina, mass in the vagina, sensation of something coming down when the polyp becomes big distending the vagina, excessive vaginal discharge which may be offensive ${ }^{1}$. Large cervical fibroid polyps are rare $\&$ handful of cases has been reported in literature ${ }^{2,3}$. Here reporting a case of big cervical fibroid polyp.

\section{CASE REPORT}

Mrs. ' $\mathrm{X}$ ' house wife para -4 ,widow of 45 years from low socio-economic condition, hailing from Boalkhali, Chittagong, got admitted through Emergency in Gynae ward, on $26^{\text {th }}$ July 2015 at $8-00 \mathrm{pm}$, with the complaints of a sudden protrusion of large mass through introitus 4 hours back. Careful history revealed that she had heaviness in introitus for months. But on the day of admission, the big mass suddenly came through the vagina and it was foul smell. There was no history of delivery in recent past. Surprisingly no other relevant history such as urinary retention or constipation was there. She had history of excessive menstruation. 
On general examination, she was anemic. Other vitals were normal.

On per vaginal examination, a big fleshy mass about $15 \mathrm{~cm}$ $\mathrm{x} 12 \mathrm{~cm}$, irregular surfaced, firm with areas of slough \& necrosis was protruded through vagina and hanging outside the introitus. On digital examination, the mass was found to be attached to the posterior lip of cervix. While we tried to find out cervical os, uterine sound could be passed through os \& uterine length was $7 \mathrm{~cm}$.

On bimanual examination, uterus was bulky. anteverted and fornices were free.

She was prepared for operation, all preoperative investigation were found normal except $\mathrm{Hb} \%$ which was $9 \mathrm{gm} / \mathrm{dl}$. Under broad spectrum antibiotics coverage, NON-DESCEND VAGINAL HYSTERECTOMY was done without resecting the polyp priorly. Peroperatively 2 units fresh whole blood were transfused.

Her post operative period was uneventful and was discharged in good health on $7^{\text {th }}$ post operative day with routine post operative advice. Histopathology report revealed leomyoma with areas degeneration.

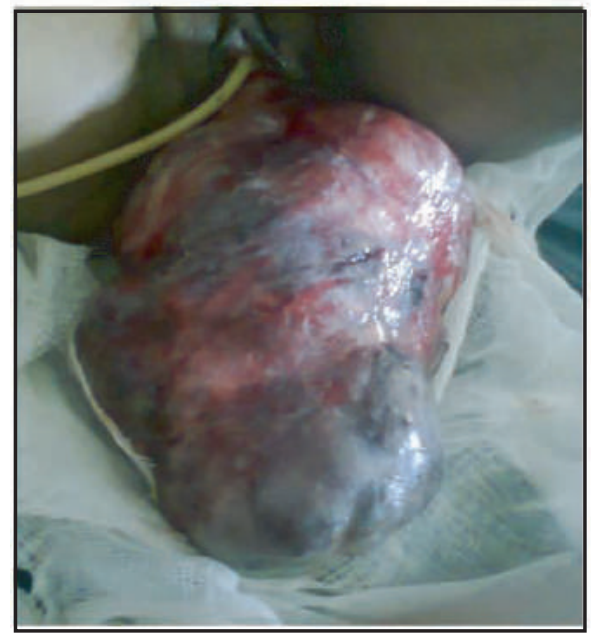

Figure 1 : Fibroid polyp prutruding through introitus.

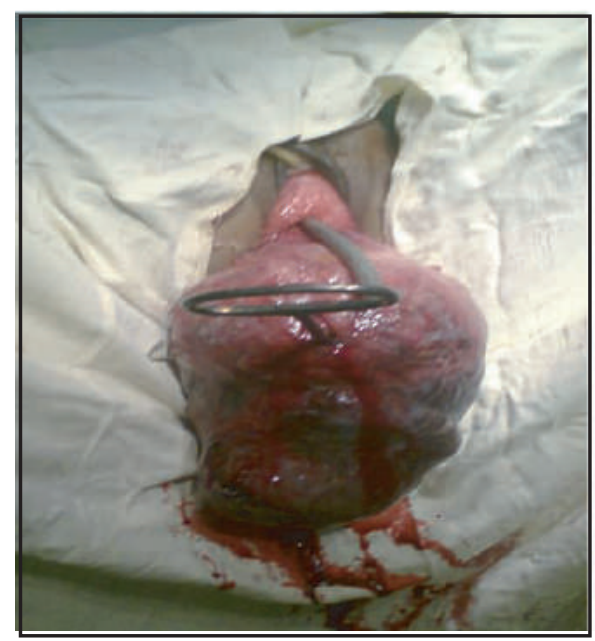

Figure 2 : Uterine sound showing Cervicalos.

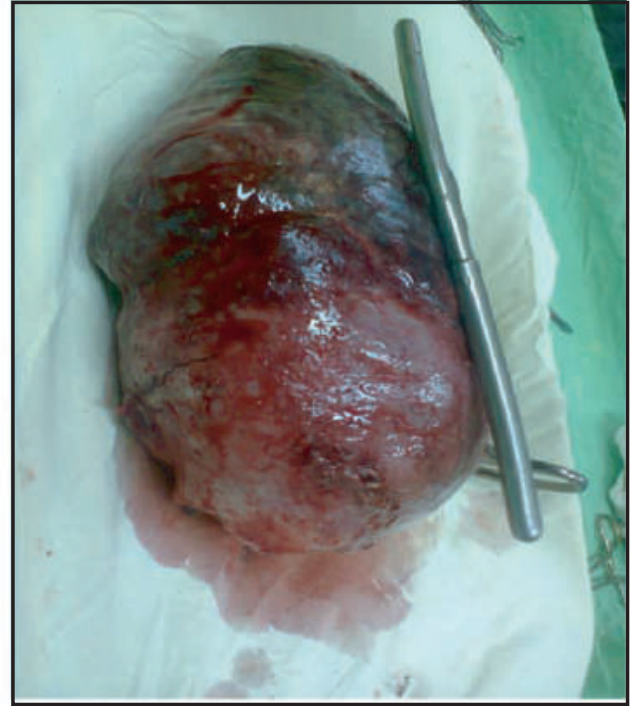

Figure 3 : Polyp size with length of Hegar's dilator.

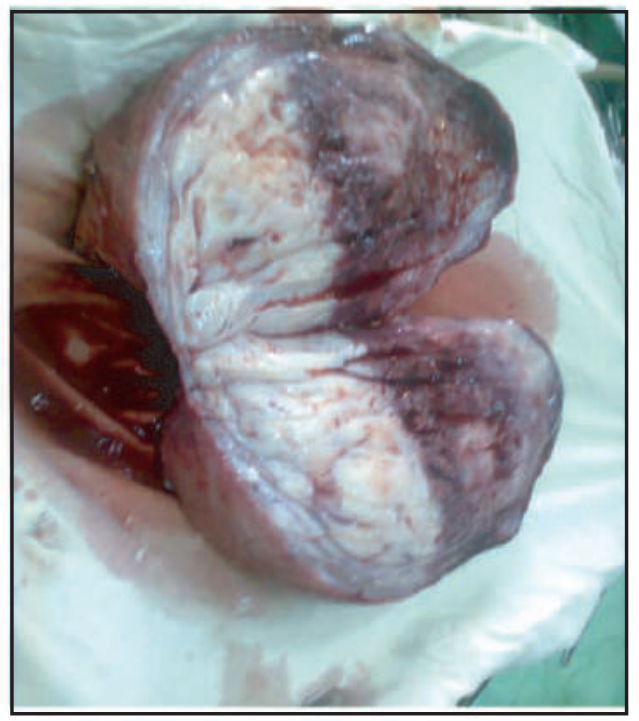

Figure 4 : Cut section of fibroid polyp.

\section{DISCUSSION}

Cervix is mainly composed of involuntary smooth muscles superiorly and fibrous connective tissue inferiorly. Probably this Leiomyoma arose from the smooth muscle and was expelled out as a polyp attached to the posterior lip of the cervix. Huge cervical fibroid polyps are rare. Saini Vandana et al, reported a case of a giant cervical fibroid which appeared as 'en caul birth' 4 . The presentations of large cervical fibroid are reported as abdominal mass, incercarated procidentia, uterine inversion, cervical malignancy etc. This case is unique as it did not give any urinary or bowel complaints. Fibroid arising from vaginal part of cervix may remain asymptomatic during non pregnant state \& produces obstruction during labour ${ }^{5}$. If it is pedunculated, there may be sensation of something coming down or infected, foul-smelling discharges per vagina ${ }^{6}$. 


\section{CONCLUSION}

Careful vaginal examination is mandatory to diagnose the cervical fibroid polyp as it may arise confusion with uterine inversion, uterine myomatous polyp, cervical malignancy \& 'en caul birth'. So management depends on actual diagnosis \& expertise decision.

\section{DISCLOSURE}

All the authors declared no competing interest.

\section{REFERENCES}

1. Benign lesions of the uterus : Dutta DC,Text book of Gynaecology including contraception India : New Central Book Agency (P) Ltd. 2004;3:264.

2. Bucello D , Frederic B, Noel JC, Giant cervical polyp : A case report and review of rare entity .Arch Gynaecol Obstet. 2008;278(3) : 2959-2988.

3. Massinde AN, Mpogoro F, Rumanyika RN , Magona M. Uterine prolapse complicated with giant cervical fibroid polyp. J Low Genit Tract Dis. 2012;16(1):64-65.

4. A giant sized cervical fibroid : Resembling En Caul Birth : Siani Vandana, Gupta Momta : Indian Journal of Basic \& Applied Medical Research. 2013;2(8):1103-1105.

5. An unusual presentation of huge cervical fibroid : Banset N, Banerjee B, Badari H, Tiwari A, Raina A, Pokharel H, Yajav, Agarwal A, Chhetri SB, P koirala : Institute of Health Sciences : Kathmandu University Medical Journal. 2005;3(2):10:173-174.

6. Incarcerated procidentia due to cervical fibroid : An unusual presentation, Sunija A, Tanija A, Gurria K, Yadav P, Agalwall N, Aust NZJ, Obstet Gynaecol. 2003; 43: 252-253. 